\title{
HEPARIN-ANTIVENOM ASSOCIATION: DIFFERENTIAL NEUTRALIZATION EFFECTIVENESS IN Bothrops atrox AND Bothrops erythromelas ENVENOMING
}

\author{
Antônio Luiz R. BOECHAT(1), Cristiano S. PAIVA(1), Francisco Oscar FRANÇA(2) \& Maria Cristina DOS-SANTOS(3)
}

\begin{abstract}
SUMMARY
Heparin, in some regions of Brazil has been used in the treatment of bothropic accidents, but the data found in the literature are inconclusive about its effectiveness. The venoms of Bothrops atrox and of B. erythromelas were characterized according to their biological activities. The capacity of heparin in neutralizing these activities was tested with doses of 3 and 6 IU in isolated form and associated to Antibothropic Serum (ABS). It was verified that heparin, in doses of 3 and 6 IU, was not effective in neutralizing the desfibrinating and edema-forming activities of $B$. atrox venom and the hemorrhagic and coagulant actions of both venoms. Heparin diminished the effectiveness of the ABS in the neutralization of the hemorrhagic and edema-forming activities of the $B$. atrox venom. However, heparin in the $6 \mathrm{IU}$ dose was capable of neutralize the edema-forming of the B. erythromelas and increase the effectiveness of the ABS. Heparin also neutralized the phospholipasic A activity of B. atrox (14.3\%) and B. erythromelas (28.0\%) venoms. For B. erythromelas venom, the associated treatment, heparin and ABS, was more effective in the neutralization of its lethal activity.
\end{abstract}

KEYWORDS: Heparin; Neutralization; Bothrops erythromelas; Bothrops atrox; Venom.

\section{INTRODUCTION}

In Brazil, snake venoms accidents represent an important public health problem. Around $90 \%$ of which are caused by snakes of the Bothrops genus. The species Bothrops jararaca (South and Southeast), Bothrops moojeni (Center-West), Bothrops erythromelas (Northeast) and Bothrops atrox (North) which are responsible for most of these accidents, with humans, are distributed in different regions of Brazil ${ }^{5}$.

Despite the interspecies and intra-species variations existent in the chemical composition of venom, generally, the signs and symptoms presented by patients that have had accidents with Bothrops genus are: (a) local - pain, edema, equimosis, hemorrhage, myonecrosis; (b) systemics - blood incoagulability, hemorrhages being it possible to also occur shock and acute kidney failure. In severe cases of envenoming, these local effects may lead to permanent tissue loss, disability or amputation $^{18,25}$.

The effective therapeutic treatment for ophidian accidents is serotherapy. Antivenom serotherapy, however, although efficient for neutralization of systemic manifestations of bothropic venom, contribute little to the improvement of the local tissue damage ${ }^{6}$. Experiments on mice, show that antivenoms are effective in neutralizing necrosis and local hemorrhage, only when injected at the same time or immediately after poison inoculation ${ }^{15,26}$. Therefore, new therapies parallel antivenom injection, would be fundamental in minimizing local effects induced by snakes venoms, specially from Bothrops genus.

The use of heparin as a treatment in snake venom accidents, was first proposed in the late 40's by AHUJA et al. ${ }^{2}$ and AHUJA \& SINGH $^{1}$.

Heparin is a family of glycosaminoglycans, highly sulfated, with molecular weight that varies between 5,000 and 40,000, capable of interacting with the antithrombin III, producing anticoagulant effect. The clinical use of heparin has been secured as anticoagulant and antithrombotic, but, recently, a possible anti-inflammatory action has been suggested ${ }^{21}$.

Due to its strongly polyanionic nature, heparin can interact with many molecules that have cationic sites ${ }^{33}$. Among the substances capable of interacting with heparin, are included proteins from the extracellular matrix (fibronectin, laminae, vitronectin), proteins involved in lipid metabolism, components of the complement system, serine protease inhibitors, viral proteins, and enzymes ${ }^{21,22,33}$. Within the enzymes, heparin can interact with phospholipase $A_{2}$, present in many snake venoms, affecting ${ }^{8,9,12}$, or not ${ }^{7,19}$ the enzymatic activity of these proteins.

TINOCO ${ }^{30}$ in a clinical and experimental study with dogs, suggested the use of heparin in substitution of specific serum therapy in the case of poisoning by Bothrops jararaca. 
In 1975, NAHAS et al. ${ }^{27}$ demonstrated that heparin was not capable of neutralizing the thrombin-like activity of bothropic venoms and in prevention of the desfibrinating syndrome, induced by Bothrops jararaca venom. Nevertheless, they observed that heparin was capable of neutralizing the venom that acts only on factor $X$. Those venoms that act directly on the fibrinogen and on factor $\mathrm{X}$, did not have their coagulant activity blocked by heparin.

Heparin neutralized the myotoxic activity of bothropstoxin enzyme of Bothrops jararacussu venom. This protein belongs to phospholipase $\mathrm{A}_{2}$ group that do not have neurotoxic activity ${ }^{23,24}$. Heparin inhibited in vitro the citotoxic activity of Bothrops asper venom and also neutralized in vivo ${ }^{22}$ its myotoxic activity.

The present experiments were undertaken to verify the action of commercial heparin (Liquemine-Roche) within the main biological activities (hemorrhagic, in vitro and in vivo coagulant, edematogenic, phospholipasic and lethality) of the Bothrops atrox and Bothrops erythromelas venoms, that are responsible for most accidents in the North and Northeast of Brazil, respectively.

\section{MATERIAL AND METHODS}

Venoms: Lyophilized venom of Bothrops atrox was obtained at the Centro de Animais Peçonhentos do Instituto de Medicina Tropical do Amazonas, Manaus (AM), Brazil. The freezing dried venom of Bothrops erythromelas was kindly given by Prof. Dr. Augusto S. Abe of the Departamento de Zoologia, Universidade Estadual de São Paulo, Rio Claro (SP), Brazil. The venoms were kept at $-20{ }^{\circ} \mathrm{C}$ and diluted at the moment of the use.

Animals: Outbred Swiss mice (18 - $22 \mathrm{~g}$ ), females proceeding from the Instituto Nacional de Pesquisas da Amazônia (INPA - Manaus, Amazonas, Brazil) were used in the experiments. The animals were kept in plastic cages receiving water and food ad libitum under controlled temperature conditions.

Bovine Fibrinogen: Samples of lyophilized bovine fibrinogen were donated by the Seção de Hematologia do Instituto Butantan (São Paulo, SP, Brazil).

Heparin (HEP): Heparin used in the experiments was purchased from Roche (Liquemine $\left.{ }^{\circledR}\right)$.

Antibothropic Serum (ABS): The antibothropic serum used in the neutralization experiments was produced by Instituto Butantan (São Paulo, SP, Brazil) -Lot 9406081.

\section{Biological activities of venoms}

Lethal Dose 50\% $\left(\boldsymbol{L} \boldsymbol{D}_{50}\right)$ : For determination of the $\mathrm{LD}_{50}$, different doses of venoms were injected by intraperitonial route (i.p). Four mice were used for each venom dose. Deaths were recorded after 24 and 48 hours. The $\mathrm{LD}_{50}$ were calculated by the probit analysis ${ }^{11}$.

Minimum Hemorrhagic Dose (MHD): Hemorrhage was quantified by the method of GUTIÉRREZ et al. ${ }^{16}$. Four mice were used for each venom dose. The venom doses were injected by intradermic route. Mice were killed by ether inhalation $2 \mathrm{hr}$ after injection, and the areas of hemorrhage measured on the internal surface of the dissected skin. The minimum hemorrhagic dose was defined as the amount of venom which induced a hemorrhagic area of $10 \mathrm{~mm}$ diameter.

Minimum Coagulant Dose: The plasma and fibrinogen minimum coagulant doses were estimated as previously described ${ }^{29}$. The minimum coagulant dose of a venom is defined as the minimum amount of venom resulting in clot formation within $60 \mathrm{sec}$ at $37^{\circ} \mathrm{C}$. The tests were done in triplicate.

Minimum Defibrinagenating Dose (MDD): For defibrinating activity the method described by GENÉ et al. ${ }^{13}$ was used. Briefly, five doses for each venom were used and, for each dose, four mice. The venom doses were inoculated by intravenous route. One hour after the injection of the venom, blood samples $(0.1 \mathrm{ml})$ were collected from the animals. Blood was placed in tubes and kept at $37{ }^{\circ} \mathrm{C}$ until clotting occurred.

Minimum Edema-forming Dose (MED): The minimum edemaforming doses were determined according to the procedures of YAMAKAWA et al. ${ }^{32}$ with some modifications. Briefly, hind paw edema was produced by a subplantar injection of $50 \mu \mathrm{l}$ venom solution or an equal volume of saline into the right and left hind-paw of mice, respectively. The paws (right and left) were measured with a calliper (Mitutoyo) at 0, 30, 60, 120, 180, 240, 300, 360 minutes. The minimum edema-forming dose was defined as the amount of venom that induced an edema of $30 \%$.

Determination of the Heparin Doses: The heparin doses were obtained with basis on that used in human therapeutics $(60 \mathrm{~kg}$ of body mass) and calculated for mice with 20 grams of body mass.

Anticoagulant Effect of the Heparin: The doses of heparin obtained by the previous method were injected in mice, by intravenous route and the effect of each dose on the blood coagulation was observed. For each dose, four mice were used.

\section{Effects of Heparin on the biological activities of Venoms}

Group Schemes for the neutralization experiments: For all the neutralization experiments (hemorrhagic, edematogenic, desfribrinating and lethality activities) six groups of four animals each were used, for each venom, and received the following treatment: group I (GI) - venom in the corresponding doses for each activity (venom control); Group II (GII) - venom and heparin in a 3 IU dose; Group III (GIII) - venom and heparin in a 6 IU dose; Group IV (GIV) - venom and Antibothropic Serum (ABS); Group V (GV) - venom, ABS and 3 IU heparin; Group VI (GVI) - venom, ABS and 6 IU heparin. The doses of heparin were

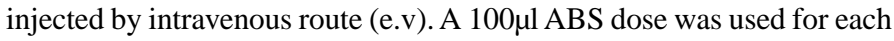
animal and injected (e.v) in all experiments. Heparin and ABS were injected immediately after injection of the venom (zero time).

- Hemorrhagic: The challenge dose used, for each venom, in the neutralization of the hemorrhagic activity corresponded to three times the Minimum Hemorrhagic Dose and was injected by intradermic route at zero time. The animals were sacrificed two hours later, with ethylic ether and the hemorrhagic halos were measured. 
- Edematogenic: The challenge dose was equivalent to three times the Minimum Edematogenic Dose of the corresponding venom and was injected in the right paw. Saline, used as control, was injected in the left paw, as described previously. The paws were measured at times $0,30,60,120,180,240,300$ and 360 minutes after injection of the venom and saline.

- Desfibrinating: The dose used, for each venom, corresponded to three times the Minimum Desfibrinating Dose and was injected by i.v. route, at zero time. Blood samples were collected one hour after the injection, kept at $37^{\circ} \mathrm{C}$ and the time of coagulation, for each blood sample, was observed for one hour.

- Lethality: A $250 \mu \mathrm{g}$ challenge dose was used for each venom injected by i.v. route, at zero time. The time of death and the reactions presented by the animals were observed and noted. The animals were submitted to necropsy and the organs (liver, lungs, kidneys, brain and heart) kept in a $10 \%$ formaldehyde solution. Histopathological analysis was performed by classical techniques.

\section{- Coagulant Activity:}

- On the fibrinogen. The dose of venom used was equivalent to two times the minimum coagulant dose on the fibrinogen (MCDF). The venom ( $2 \mathrm{MCD}-\mathrm{F})$ was incubated at $37^{\circ} \mathrm{C}$, along with the different doses of heparin $(3,6,12,24,48 \mathrm{IU})$ for 30 minutes. After incubation, $100 \mu$ l of each venom solution and HEP were added to $400 \mu \mathrm{l}$ of Bovine fibrinogen $(2 \mathrm{~g} / \mathrm{L})$ and the time of coagulation was observed.

- On the plasma. The dose of venom used was equivalent to two times the minimum coagulant dose on human plasma, used as substrate, following the methodology mentioned above.

- Phospholipase $A_{2}$ Activity (Indirect Hemolytic Assay): The method described by GUTIÉRREZ et $a l .{ }^{17}$ was used to evaluate this activity. $100 \mu \mathrm{l} \mathrm{samples}$ of venom solution $(10 \mathrm{mg} / \mathrm{ml})$ were incubated with $100 \mu \mathrm{l}$ of heparin, $\mathrm{ABS}$ and saline, at $37^{\circ} \mathrm{C}$, for 30 minutes. After incubation, $10 \mu \mathrm{l}$ of each mixture was added to wells, previously covered with agarose containing sheep erythrocytes and egg yolk. The hemolysis halos were measured 24 hours after sample application.

- Statistical Analysis. The T Student test was applied, using the Statgraphics Plus statistical program to verify the statistical difference between groups. The value of $\mathrm{p}=0.05$ was defined.

\section{RESULTS AND DISCUSSION}

Characterization of Biological Activities of the Venoms: The values obtained for the minimum doses of venoms activities are showed in Table 1 . These values were similar to the ones described by other authors ${ }^{3,10,28}$. The venom of the Bothrops erythromelas has no coagulant activity on bovine fibrinogen. This venom, however, was more toxic, for the lethal and coagulant activities on the plasma, than the venom of the $B$. atrox and less active, for the edematogenic, hemorrhagic and desfibrinating actions. Although FERREIRA et al. ${ }^{10}$ showed that hemorrhagic and edematogenic actions are related to the lethality of bothropic venom, this fact was not observed in this experiments.
Determination of Experimental Doses of Heparin: The doses of heparin used on mice corresponding to the ones injected, in human therapeutics, for individuals weighing $60 \mathrm{~kg}$. From the blood samples collected from the animals that received different doses of heparin $(3,6$, $12,24$ and $48 \mathrm{IU})$ it was observed that the blood coagulation time remained normal ( $<5$ minutes) for the animals that received 3 and 6 IU heparin doses. The time of blood coagulation was altered, occurring the formation of microclots and coagulation after 30 minutes, for the animals that received the 12 UI dose; and uncoagulative (> 60 minutes) for the animals that received the 24 and 48 IU doses. Based on these results, 3 and $6 \mathrm{IU}$ heparin doses were chosen for the neutralization tests, since the higher doses would induce alterations in the blood coagulation.

Study of Neutralizing Effect of Heparin on the Coagulant Activity: Heparin was capable of neutralizing the thrombin time coagulant activity of the B. atrox (Table 2) only in the doses over 12 IU (equal to 36,000 IU in human therapeutics).

Table 1

Establishment of the minimum doses for the venom of Bothrops atrox and Bothrops erythromelas

\begin{tabular}{lcc}
\hline Biological Activities & $\begin{array}{c}\text { Bothrops } \\
\text { atrox }\end{array}$ & $\begin{array}{c}\text { Bothrops } \\
\text { erythromelas }\end{array}$ \\
\hline Lethality $\left(\mathrm{LD}_{50}\right)$ & $\begin{array}{c}5.6 \mathrm{mg} / \mathrm{kg} \\
(4.4-6.6 \mathrm{mg} / \mathrm{kg})\end{array}$ & $\begin{array}{c}3.0 \mathrm{mg} / \mathrm{kg} \\
(2.5-3.5 \mathrm{mg} / \mathrm{kg})\end{array}$ \\
$\begin{array}{l}\text { Coagulant on Fibrinogen } \\
\text { (MCD-F) }\end{array}$ & $77.5 \mathrm{mg} / \mathrm{l}$ \\
Coagulant on Plasma (MCD-P) & $150.0 \mathrm{mg} / \mathrm{l}$ & \\
Edematogenic (MED) & $1.2 \mu \mathrm{g} / \mathrm{animal}$ & $1.4 \mu \mathrm{g} / \mathrm{animal}$ \\
Hemorrhagic (MHD) & $2.9 \mu \mathrm{g} / \mathrm{animal}$ & $5.9 \mu \mathrm{g} / \mathrm{animal}$ \\
Desfibrinating (MDD) & $10.0 \mu \mathrm{g} / \mathrm{animal}$ & $45.0 \mu \mathrm{g} / \mathrm{animal}$ \\
\hline
\end{tabular}

* B. erythromelas venom did not present coagulant activity on the bovine fibrinogen.

Heparin did not present, in the tested doses, inhibitory effect of the coagulant action of $B$. atrox venom on the human plasma (Table 2). However, in the 12, 24 and 48 IU doses, heparin was capable of partially neutralize the coagulant action of $B$. erythromelas venom on the plasma (Table 2).

NAHAS et $a l .{ }^{27}$ demonstrated that heparin neutralizes only the coagulant activity of venoms that act selectively on the factor $\mathrm{X}$ of the blood coagulation system. This is the reason that heparin did not inhibit the coagulant activity of $B$. atrox venom, since this venom acts on factor $\mathrm{X}$, on the prothrombin, and on the flbrinogen (thrombin-like action). The B. erythromelas venom which acts on the factor $\mathrm{X}$ and does not have thrombin-like activity, explains the partial neutralization by heparin of the coagulant activity on the human plasma.

Neutralizing Effect of Heparin on the Desfibrinating Activity: The 


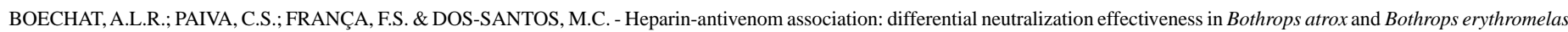
envenoming. Rev. Inst. Med. trop. S. Paulo, 43(1):7-14, 2001.

Table 2

Neutralization of the coagulant activity of the venoms

\begin{tabular}{ccccc}
\hline $\begin{array}{c}\text { Heparin } \\
\text { (IU) }\end{array}$ & \multicolumn{2}{c}{$\begin{array}{c}\text { Bovine Fibrinogen } \\
(\text { min. })\end{array}$} & \multicolumn{2}{c}{$\begin{array}{c}\text { Human Plasma } \\
(\mathrm{sec})\end{array}$} \\
\cline { 2 - 5 } & B. atrox & B. erythromelas & B. atrox & B. erythromelas \\
\hline- & $<2$ & $*$ & 51 & 62.5 \\
3 & $<2$ & $*$ & 48 & 62 \\
6 & $<2$ & $*$ & 54 & 63 \\
12 & $>60$ & $*$ & 55 & 91 \\
24 & $>60$ & $*$ & 63 & 127 \\
48 & $>60$ & $*$ & 44 & 146 \\
\hline
\end{tabular}

* B. erythromelas venom did not present coagulant activity on the bovine fibrinogen.

results presented in Table 3 demonstrate that heparin was not capable of neutralizing the desfibrinating action (MDD), in vivo, of the B. atrox venom in the doses tested. On the other hand, the antibothropic serum (ABS) was capable of totally neutralizing this activity, and its action was not affected when associated with heparin (Table 3).

Table 3

Neutralization of the desfibrinating activity of Bothrops atrox venom by heparin

\begin{tabular}{cccc}
\hline Heparin (IU) & Venom & Antibothropic & $\begin{array}{c}\text { Time of Coagulation } \\
(\mathrm{min})\end{array}$ \\
\hline- & + & - & $>60$ \\
3 & + & - & $>60$ \\
6 & + & - & $>60$ \\
- & + & + & $<10$ \\
3 & + & + & $<10$ \\
6 & + & + & $<10$ \\
\hline
\end{tabular}

Due to the proximity of the Lethal Dose $50 \%$ and the Minimum Desfibrinating Dose (MDD) of B. erythromelas venom (see Table 1), it was not possible to study the neutralizing effect of the heparin, since the animals died before one hour after the injection of three times the MDD.

Neutralizing Effect of Heparin on the Hemorrhagic Activity: Heparin did not neutralize the hemorrhagic activity of $B$. atrox venom as shown in Table 4. There was a significant dose-dependent increase of the hemorrhagic halo produced by the venom, compared to the control, when the animals received heparin ( 3 and 6 IU doses) at the same time (Table 4).

The antibothropic serum (ABS) was capable of neutralizing 38\% of the hemorrhagic activity of $B$. atrox venom. The antivenom's action was totally neutralized when the animals were treated with ABS and heparin in the 3 and 6 IU doses, being observed, in these groups, significant increases of the hemorrhage compared to the group that received antibothropic serum, alone. MELO et al. ${ }^{24}$ reported that polyanions with high molecular weight, as heparin family, are not effective in neutralizing the hemorrhagic activity of $B$. jararacussu venom. LOMONTE et al. ${ }^{22}$ demonstrated through histological sections that hemorrhagic activity of $B$. asper venom was potencialized by addition of heparin standard solution, which has high molecular weight polyanions capable of interacting with the antithrombin III, promoting the anticoagulant effect. In addition, when low weight heparin was used, the increase in the hemorrhagic activity was not observed ${ }^{22}$.

There was no significant difference between the hemorrhage produced by $B$. erythromelas venom in the control and experimental groups that received heparin ( 3 and 6 IU doses). The bothropic antivenom, on the other hand, was capable of neutralizing $57 \%$ of the hemorrhagic activity, without having its action harmed by the heparin in the studied doses -3 and 6 IU.

Neutralizing Eftect of Heparin on the Edematogenic Activity: Figure 1 shows the action of heparin, in the 3 and 6 IU doses, on the kinetics of edema formation produced by the venom of $B$. atrox in the dose corresponding to three times the Minimum Edema-forming Dose (MED). It was observed that the antibothropic serum reduced, in a significant way, the edema from 180 minutes on, obtaining its maximum effect of neutralization (44.6\%), in 360 minutes. GUTIÉRREZ \& LOMONTE $^{18}$ demonstrated that the antivenoms are not capable of totally neutralizing the edematogenic activity. Heparin, by itself, did not induce a significant reaction in the edema levels. Interestingly, the presence of heparin decreased the anti-edematogenic activity of the antiserum. The results presented for the edematogenic action of $B$. atrox venom show that heparin was not effective in neutralizing this activity.

Effects of heparin, in the 3 and $6 \mathrm{IU}$ doses, on the edematogenic activity of $B$. erythromelas venom are expressed in Figure 2. It was observed that the bothropic antivenom promoted an $85.8 \%$ reduction of the edema

Table 4

Neutralization of the hemorrhagic activity of the venom of the Bothrops atrox and Bothrops erythromelas

\begin{tabular}{lccc}
\hline Groups & $\begin{array}{c}\text { Hemorrhagic area }\left(\mathrm{mm}^{2}\right) \\
\text { Bothrops atrox }\end{array}$ & $\begin{array}{c}\text { Protection } \\
(\%)\end{array}$ & $\begin{array}{c}\text { Hemorrhagic area }\left(\mathrm{mm}^{2}\right) \\
\text { Bothrops erythromelas }\end{array}$ \\
\hline Control (venom) & $128.2 \pm 14.5$ & - & $310.3 \pm 41.2$ \\
Heparin 3UI & $169.2 \pm 14.1$ & - & $399.2 \pm 56.5$ \\
Heparin 6 UI & $207.3 \pm 22.3$ & - & $401.3 \pm 109.9$ \\
Antibothropic & $78.6 \pm 22.2$ & 38.7 & $130.3 \pm 37.2$ \\
Antibothropic + heparin 3 UI & $132.3 \pm 18.9$ & - & - \\
Antibothropic + heparin 6 UI & $138.0 \pm 6.1$ & - & 57.9 \\
\hline
\end{tabular}




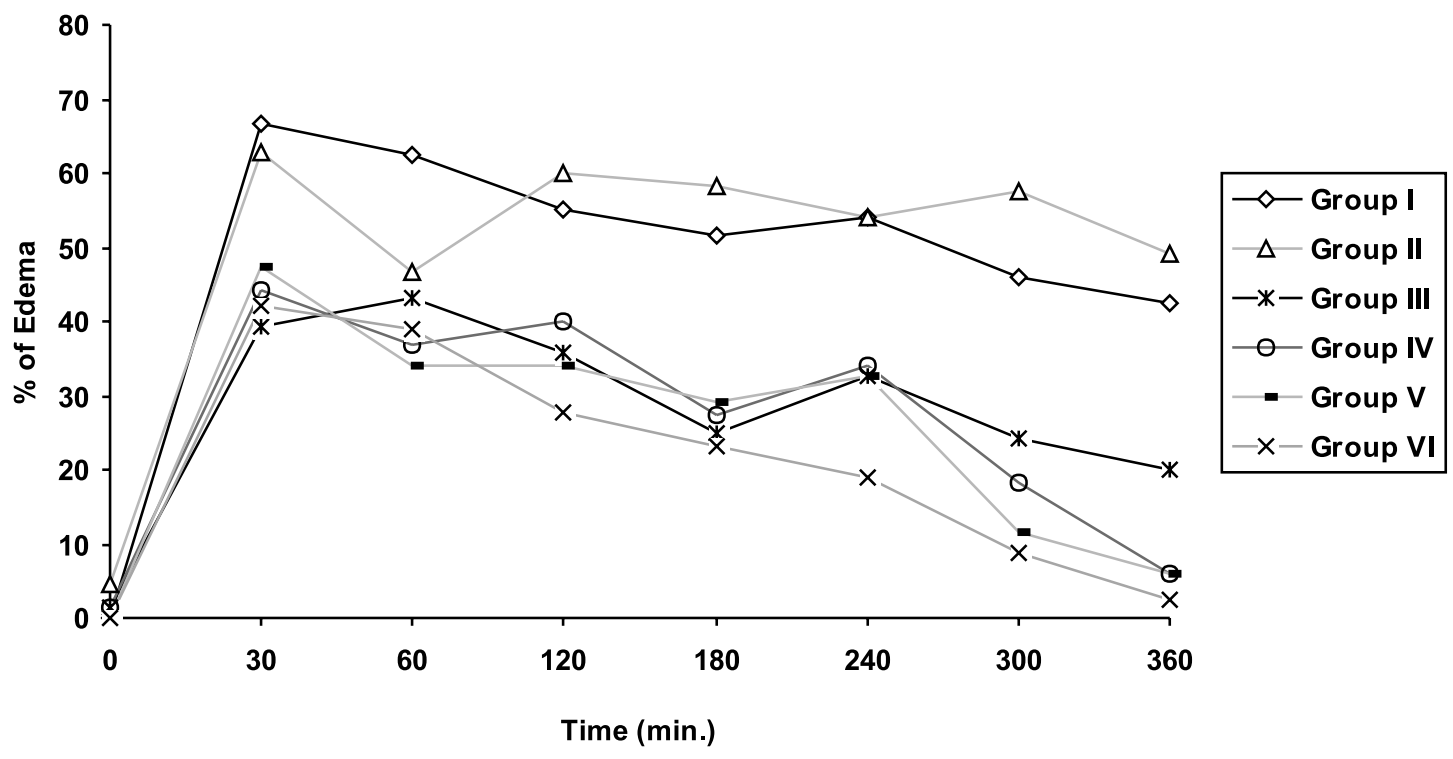

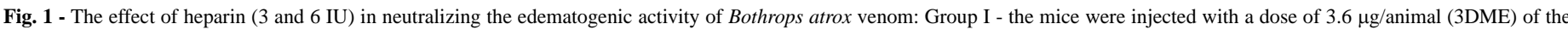

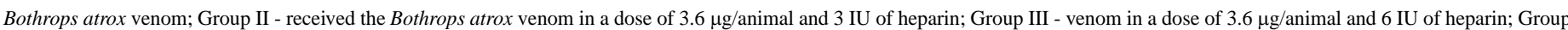

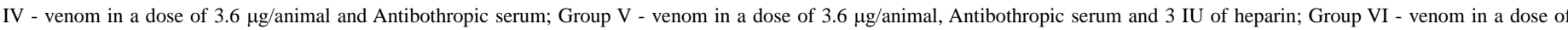
$3.6 \mu \mathrm{g} / \mathrm{animal}$, Antibothropic serum and $6 \mathrm{IU}$ of heparin.

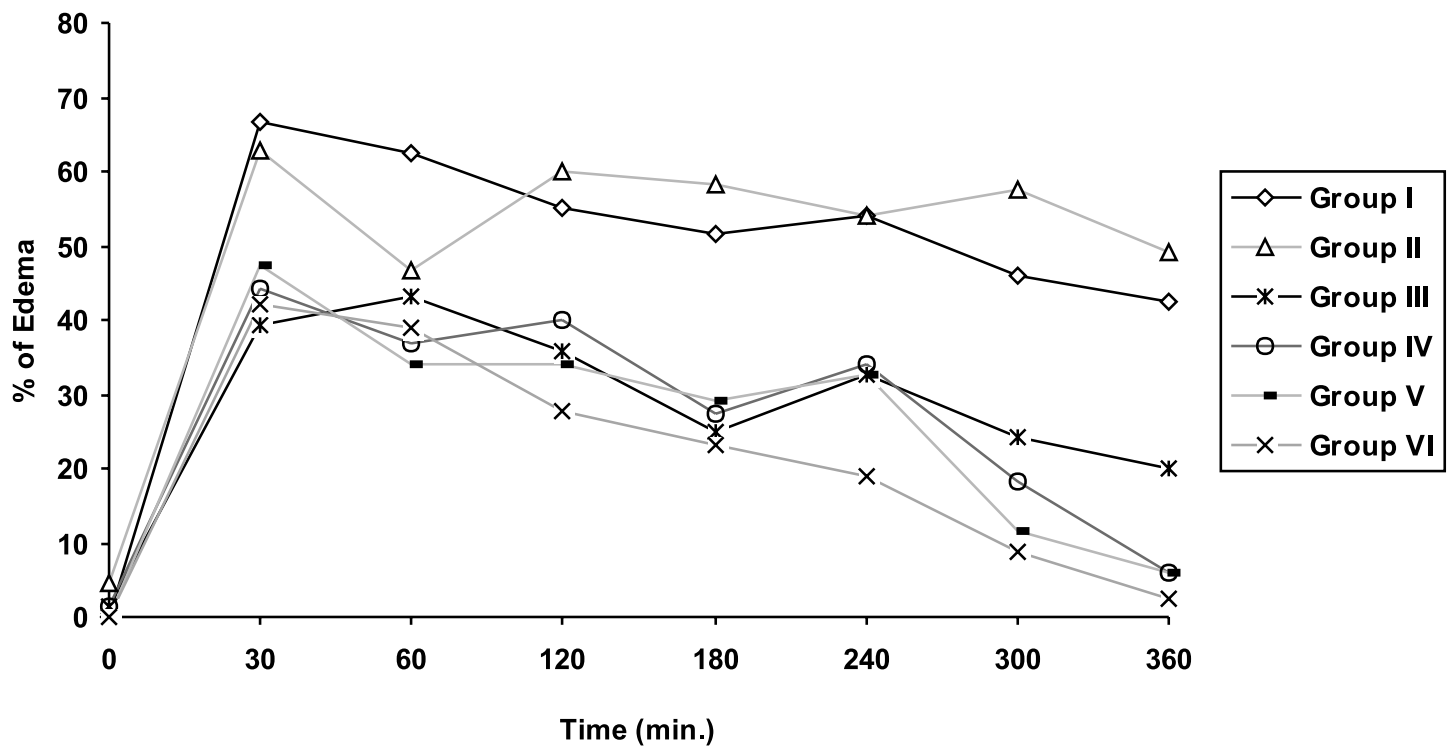

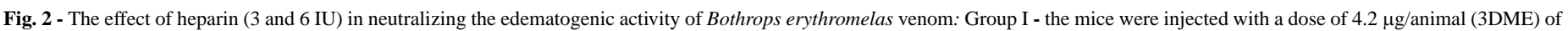

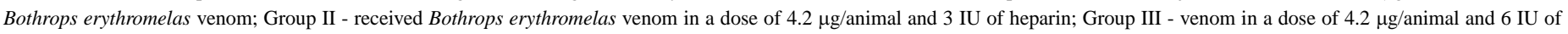

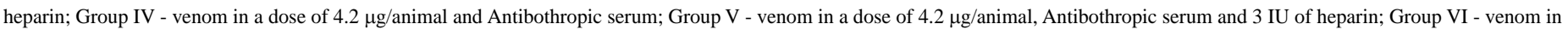
a dose of $4.2 \mu \mathrm{g} / \mathrm{animal}$, Antibothropic serum and $6 \mathrm{IU}$ of Heparin. 


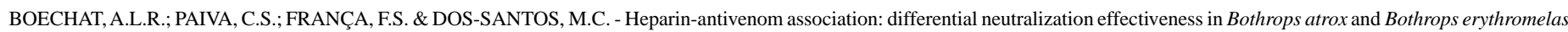
envenoming. Rev. Inst. Med. trop. S. Paulo, 43(1):7-14, 2001.

Table 5

Neutralization of the phospholipase $\mathrm{A}_{2}$ activity of the venom Bothrops atrox and Bothrops erythromelas

\begin{tabular}{cccccc}
\hline Bothrops atrox & Bothrops erythromelas & Heparin (IU) & Antibothropic & Hemolysis halo $\left(\mathrm{mm}^{2}\right)$ & Neutralization $(\%)$ \\
\hline+ & - & - & - & 2.1 & 1.8 \\
+ & - & + & - & 1.6 & 14.3 \\
+ & - & - & + & 2.5 & 2.8 \\
- & + & + & - & 1.8 & 2.8 \\
- & + & - & - & 2.1 & \\
-
\end{tabular}

produced by this venom, in the sixth hour after injection. Heparin caused a significant anti-edematogenic effect only in the $6 \mathrm{IU}$ dose. It is interesting to note that, up to 180 minutes, the effect of the heparin does not significantly differ from the neutralizing effect produced by the antibothropic, having it promoted maximum neutralizing effect $(52.9 \%)$ in 360 minutes. When associated to the antibothropic venom, heparin induced according to the dose the following results: (a) with 3 IU dose, the neutralization did not differ from that produced by the antivenom, alone; (b) with 6 IU dose, the action of the antibothropic improved, at the sixth hour (360 minutes), reducing the edema formation to $94.1 \%$.

The neutralization of local action of $B$. atrox venom by the antibothropic and by the heparin was less effective than B. erythromelas venom (Figures 1 and 2). This phenomenon can be explained considering the difference of the phospholipasic and proteolytic activities of both venoms. The indirect hemolytic activity (by phospholipase $\mathrm{A}_{2}$ ) of the venom is presented in Table 5, showing that the venom of $B$. erythromelas has a higher phospholipasic $\mathrm{A}_{2}$ activity. $B$. atrox venom is known as one of the most proteolytic bothropic venoms ${ }^{3,10,28}$. Furthermore, it is more hemorrhagic than $B$. erythromelas venom. Therefore, it is possible to suggest that the edematogenic activity of $B$. atrox venom may be related with the proteolytic and hemorrhagic activities. On the other hand, the edematogenic activity of B. erythromelas venom may be due to a potent phospholipasic activity. The observation of necrosis, flictens and hemorrhage on the paws of the animals that received the venom of the Bothrops atrox corroborates this hypothesis. Animals that received Bothrops erythromelas venom, besides edema, presented only a discreet local hemorrhagic action, without signs of macroscopic tissue destruction. According to this hypothesis, the intense tissue destruction produced by the Bothrops atrox venom (microvasculature, conjunctive tissue), along with the overcoming of the microtrombs ${ }^{18}$ hinders the access of antibodies and heparin to the site of venom inoculation.

Finally, it remains to explain how heparin contributes to reduce the levels of edema produced by $B$. erythromelas venom. It is known that heparin is constituted of radical sulfates, which make it possible to interact electrostaticaly with diverse proteic locations of a basic character, including phospholipase $\mathrm{A}_{2}$ which is present in the Bothrops atrox, $B$. erythromelas and in diverse venom of other kinds and species of snakes ${ }^{21}$. Heparin was capable of neutralizing the phospholipasic activity of the Bothrops atrox and Bothrops erythromelas venom on an average of $14.3 \%$ and $28.0 \%$ respectively (Table 5). Given that fact, the Bothrops erythromelas venom produces less local tissue destruction allowing heparin access to the inoculation site where, by electrostatic interaction, it would reduce the phospholipasic activity of Bothrops erythromelas venom, with a consequent reduction of edema.
Study of Neutralizing Effect of Heparin on Lethality: Heparin (dose 3 IU), prolonged Time of Death of the animals which received the Bothrops atrox and Bothrops erythromelas venom, but did not keep the animals alive (Table 6). The animals that received the venom with heparin presented macroscopic lesions of greater intensity. 1t is interesting to point out that there was a difference in the macroscopic lesions provoked by the venom; those that received the Bothrops atrox venom died with rhinorrhagia, not present in the control animals and in those which received the Bothrops erythromelas venom.

Table 6

Effect of the Heparin (3 IU) on time of death

\begin{tabular}{lcc}
\hline \multicolumn{1}{c}{ Groups } & \multicolumn{2}{c}{ Time of Death (min) } \\
\hline Control (Venom) & $9.0 \pm 2.6$ & $5.3 \pm 0.3$ \\
Heparin 3 UI & $26.7 \pm 18.4$ & $11.2 \pm 1.9$ \\
Antibothropic & - & $*$ \\
Antibothropic + Heparin 3UI & - & $* *$ \\
\hline
\end{tabular}

(-) did not die; $(*)$ protection of $58 \% ;(* *)$ protection of $92 \%$

Necropsy revealed that envenomed mice treated with heparin presented, when compared with control animals: (a) more intense intracranial hemorrhaging; (b) macroscopic signs of intense pulmonary hemorrhaging; (c) a higher increase in the weights of lungs and brain. However, the increase was not statistically significant. On the other hand, the hystological sections of the animals injected with Bothrops atrox venom confirmed the intensity of lesions observed macroscopically, as well as confirmed that heparin potentialized the hemorrhagic activity, even in small doses (3IU) (personal communication of Dr. Luiz Carlos de Lima Ferreira - Laboratório de Patologia, Instituto de Medicina Tropical do Amazonas, Manaus, Amazonas, Brazil).

Many authors reported intracranial hemorrhaging produced by ophidian accidents ${ }^{4,14,31}$. KOUYOUMDJIAN ${ }^{20}$, showed six cases of patients with serious bothropic poisoning experiencing intracranial hemorrhaging, where four led to death, one survived with sequel and one without it. This indicates that the poisoning produced in Time of Death experiment was serious. Comparing the groups by intensity of the hemorrhagic phenomena, it suggests that heparin can increase the gravity of the accidents.

The antibothropic serum was more effective in neutralizing the lethality of the Bothrops atrox venom (100\% protection), but promoted 
only 58\% protection against the lethality of the Bothrops erythromelas venom. Heparin increased the efficacy of the bothropic antivenom for Bothrops erythromelas when associated with this antivenom $(92 \%$ protection). A possible explanation could be that heparin interacted with diverse fractions of the venom making the efficacy of the antibothropic better, considering that heparin does not interfere with the ability of the antibothropic in neutralizing the hemorrhagic activity of Bothrops erythromelas venom (Table 4).

The differences observed in the neutralization of the activities of both venom calls into question the efficacy of the antibothropic serum supplied by the Ministry of Health. The Antibothropic Serum (ABS) was less effective in neutralizing the lethal activity of Bothrops erythromeIas venom. This snake is responsible for most of the ophidian accidents in Northeast of Brazil and its venom is not included in the production of this immunobiologic.

\section{RESUMO}

\section{Associação de heparina e antiveneno: eficácia da neutralização dos venenos de Bothrops atrox e Bothrops erythromelas}

A heparina tem sido utilizada no tratamento dos acidentes botrópicos em algumas regiões do Brasil, porém, os dados encontrados na literatura são inconclusivos sobre sua eficácia. Os venenos de Bothrops atrox e de B. erythromelas foram caracterizados segundo suas atividades biológicas. A capacidade da heparina em neutralizar estas atividades foi testada com as doses de 3 e 6UI de forma isolada e associada ao soro Antibotrópico (SAB). Verificou-se que a heparina nas doses de 3 e 6UI, não foi eficaz em neutralizar a atividade desfibrinante e edematogênica do veneno de B. atrox e as ações hemorrágica e coagulante dos dois venenos. A heparina diminuiu a eficácia do soro $\mathrm{SAB}$ na neutralização das atividades hemorrágica e edematogênica do veneno de $B$. atrox. Contudo, a heparina na dose de 6UI foi capaz de neutralizar a atividade edematogênica do veneno de $B$. erythromelas e aumentar a eficácia do soro SAB. A heparina neutralizou ainda a atividade fosfolipásica $\mathrm{A}_{2}$ dos venenos de $B$. atrox (14,3\%) e de B. erythromelas (28,0\%). Para o veneno de B. erythromelas, o tratamento associado de heparina e soro $\mathrm{SAB}$, foi mais eficaz na neutralização da atividade letal.

\section{REFERENCES}

1. AHUJA, M.L. \& SINGH, G. - Snake bite in India. Indian J. med. Res., 42: 661-686, 1954

2. AHUJA, M.L.; VEERARAGHAVAN, N. \& MENON, I.G.K. - Action of heparin on the venom of Echis carinatus. Nature (Lond.), 158: 878, 1946.

3. ASSAKURA M.T.; FURTADO, M.F. \& MANDELBAUMM, F.R. - Biochemical and biological differentiation of the venoms of Lanceheads vipers (B. atrox, B. asper, $B$. marajoensis and B. moojeni). Comp. Biochem. Physiol., 102b: 727-732, 1992.

4. BURKE, C.W. - The anterior pituitary, snake bite and Sheehan's syndrome. Quart. J. Med., 75: 331-333, 1990.

5. CARDOSO, J.L.C. - Bothropic accidents. Mem. Inst. Butantan, 52 (suppl.): 43-44, 1990.

6. CARDOSO, J.L.C.; FAN, H.W.; FRANÇA, F.O.S. et al. - Randomized comparative trial of three antivenoms in the treatment of envenoming by lance-headed vipers (Bothrops jararaca) in São Paulo, Brazil. Quart. J. Med., 86: 315-325, 1993.

7. CONDREA, E. \& DE VRIES, A. - Hemolysis and splitting of human erythrocyte phospholipids by snake venoms. Biochim. Biophys. Acta, 84: 60-73, 1964.
8. DICCIANNI, M.B.; MISTRY, M.J.; HUG, K. \& HARMONY, J.A.K. - Inhibition of phospholipase $\mathrm{A}_{2}$ by heparin. Biochim. Biophys. Acta, 1046: 242-248, 1990.

9. DICCIANNI, M.B.; LILly STAUDERMAN, M.; MCLEAN, L.R.; BALASUBRAMANIAM, A. \& HARMONY, J.A.K. - Heparin prevents the binding of phospholipase $A_{2}$ to phospholipid micelles: importance of the amino-terminus. Biochemistry, 30: 9090-9097, 1991.

10. FERREIRA, M.L.; MOURA-DA-SILVA, A.M.; FRANÇA, F.O.S.; CARDOSO, J.L.C. \& MOTA, I. - Toxic activities of venoms from nine Bothrops species and their correlation with lethality and necrosis. Toxicon, 30: 1603-1608, 1992.

11. FINNEY, D.J. - Probit analysis. 3. ed. Cambridge, Cambridge University Press, 1971.

12. FRANSON, R.; PATRIARCA, P. \& ELSBACH, P. - Phospholipid metabolism by phagocytic cells. Phospholipases $\mathrm{A}_{2}$ associated with rabbit polymorphonuclear leukocyte granules. J. Lipid Res., 15: 380-388, 1974.

13. GENÉ, J.A.; ROY, A.; ROJAS, G.; GUTIÉRREZ, J.M. \& CERDAS, L. - Comparative study on coagulant, desfibrinating, fibrinolytic and fibrogenolytic activities of Costa Rican crotaline snake venoms and their neutralization by a polyvalent antivenom. Toxicon, 27: 841-848, 1989 .

14. GUPTA, P.K. - Billateral thalamic hematoma following snake bite [letter]. J. Ass. Phycns. India, 40: 549-550, 1992.

15. GUTIÉRREZ, J.M.; CHAVES, F.; BOLAÑOS, R. et al. - Neutralización de los efectos locales del veneno de Bothrops asper por un antiveneno polivalente. Toxicon, 19: 493-500, 1981.

16. GUTIÉRREZ, J.M.; GENÉ, J.A.; ROJAS, G. \& CERDAS, L. - Neutralization of proteolitic and hemorrhagic activities of Costa Rican snake venoms by a polyvalent antivenom. Toxicon, 23: 887-893, 1985

17. GUTIÉRREZ, J.M.; AVILA, C.; ROJAS, G. \& CERDAS, L. - An alternative in vitro method for testing the potency of the polyvalent antivenom produced in Costa Rica. Toxicon, 26: 411-413, 1988 .

18. GUTIÉRREZ, J.M. \& LOMONTE, B. - Local tissue damage induced by Bothrops snakes. Mem. Inst. Butantan, 51:211-223, 1989

19. HORIGOME, K.; HAYAKAWA, M.; INOUE, K. \& NOJIMA, S. - Purification and characterization of phospholipase $\mathrm{A}_{2}$ released from rat platelets. J. Biochem., 101: 625-631, 1987.

20. KOUYOUMDJIAN, J.A. - Intracranial haemorrhage after snake bite. Mem. Inst. Butantan, 52(supl.): 45, 1990.

21. LANE, D.A. \& ADAMS, L . - Non-anticoagulant uses of heparin. New Engl. J. Med., 329: $129-130,1993$

22. LOMONTE, B. - Tissue damage and inflammation induced by snake venoms. Sweden, University of Göteborg, 1994.

23. MELO, P.A. \& SUAREZ-KURTZ, G. - Release of sarcoplasmatic enzymes from skeletal muscle by Bothrops jararacussu venom: antagonism by heparin and by the serum of South American marsupials. Toxicon, 26: 87-95, 1988.

24. MELO, P.A.; HOMSI-BRANDEBURGO, M.I.; GIGLIO, J.R. \& SUAREZ-KURTZ, G - Antagonism of the myotoxic effect of Bothrops jararacussu venom and Bothropstoxin by polyanions. Toxicon, 31: 285-291, 1993.

25. MINISTÉRIO DA SAÚDE \& FUNDAÇÃO NACIONAL DE SAÚDE - Manual de diagnóstico e tratamento de acidentes por animais peçonhentos. Brasília, 1998.

26. MORAIS, J.F.; FREITAS, M.C.W.; YAMAGUCHI, I.K.; DOS-SANTOS, M.C. \& DIAS DA SILVA, W. - Snake antivenoms from hyperimmunized horses: comparison of the antivenom activity and biological properties of their whole $\mathrm{IgG}$ and $\left.\mathrm{F}(\mathrm{ab})_{2}\right)_{2}$ fragments. Toxicon, 32: 725-734, 1994 


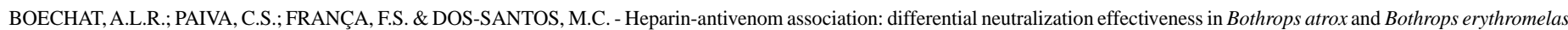
envenoming. Rev. Inst. Med. trop. S. Paulo, 43(1):7-14, 2001.

27. NAHAS, L.; KAMIGUTI, A.S.; RZEPPA, H.W.; SANO, I.S. \& MATSUNAGA, S. Effect of heparin on the coagulant action of snake venoms. Toxicon, 13: 457-463, 1975 .

28. SANCHEZ, E.F.; FREITAS, T.V.; FERREIRA-ALVES, D.L. et al. - Biological activities of venoms from South American snakes. Toxicon, 30: 95-103, 1992.

29. THEAKSTON, R.D.G. \& REID, H.A. - Development of simple standard assay procedures for the characterization of snake venoms. Bull. Wld. HIth. Org., 61: 949-956, 1983.

30. TINOCO, R.C. - Picada de cobra (uso de heparina como substituto de soro antiofídico). J. bras. Med., 23: 109-114, 1972.
31. TRAVETT, A.J.; NWOKOLO, N.C.; KEVAU, I.H. \& SEATON, R.A. - Cerebrovascular accident after Taipan bite [letter]. Med. J. Aust., 160: 94, 1994.

32. YAMAKAWA, M.; NOZAKI, M. \& HAKAMA, Z. - Fractionation of sakishima-habu (Trimeressurus elegans) venom and lethal haemorrhagic and edema-forming activities of the fraction. Animal Plant \& Microbial Toxins, 1: 98-111, 1976.

33. ZHOU, F.; HÖÖK, T.; THOMPSON, J.A. \& HÖÖK, M. - Heparin protein interations In: LANE, D.A.; BJÖRK, I. \& LINDADAHL, U., ed. Heparin and related polysaccharides. New York, Plenum Press, 1992. p.141-153.

Received: 19 November 1999

Accepted: 10 October 2000 